\title{
Deeper, Larger, More Common: Cryptic Coral Species Podabacia Benefits from Reef Recovery
}

\author{
Andreas Kunzmann ${ }^{1^{*}}$, Samsuardi ${ }^{2}$, Ofri Johan ${ }^{3}$ and Karin Springer ${ }^{4}$ \\ ${ }^{1}$ Leibniz Centre for Tropical Marine Research (ZMT), Bremen, Germany. \\ ${ }^{2} \mathrm{CV}$ Sanari, Padang, Indonesia. \\ ${ }^{3}$ Ministry of Marine Affairs and Fisheries, Jakarta, Indonesia. \\ ${ }^{4}$ Bremen University, Marine Botany, Bremen, Germany.
}

\begin{abstract}
Authors' contributions
This work was carried out in collaboration among all authors. Authors AK and KS designed the study, performed fieldwork and wrote the first draft of the manuscript. Authors OJ and Samsuardi supported the fieldwork. All authors read and approved the final manuscript.

Article Information

DOI: $10.9734 / A R R B / 2020 / v 35 i 1230309$

Editor(s):

(1) Dr. Paola Angelini, University of Perugia, Italy.

Reviewers:

(1) Carlos Augusto Oliveira de Meirelles, Universidade Federal do Ceará, Brazil.

(2) Ernesto Ron, Universidad de Oriente, Venezuela.

Complete Peer review History: http://www.sdiarticle4.com/review-history/63060
\end{abstract}

Short Communication

Received 10 September 2020

Accepted 14 November 2020

Published 10 December 2020

\begin{abstract}
In 2000 a protected area of 20,000 ha was established in West Sumatra, Indonesia (MPA Pulau Pieh) and the partial reef recovery is well documented. During monitoring of destructed reefs, a new cryptic mushroom coral species, Podabacia kunzmanni, was detected. It is not common, with rather occasional occurrence and most specimens are small. During recent visits in 2018 and 2019, the authors detected numerous specimens, mainly at three locations within the MPA Pulau Pieh, mainly at Pulau Pandan. Most individuals were found in greater depth, down to $18 \mathrm{~m}$, reaching diameters of up to $20 \mathrm{~cm}$. With regard to size, depth distribution and abundance, three new records can be established for this species. There are two potential explanations for finding them mainly on dead reefs: either they are better survivors or they are better colonizers of dead coral substrata. The team is presently collecting more data on the distribution and the reasons behind the sudden rise in visibility.
\end{abstract}

Keywords: Coral reef; MPA; mushroom coral; Indonesia; cryptic species.

${ }^{*}$ Corresponding author: E-mail: andreas.kunzmann@leibniz-zmt.de; 


\section{INTRODUCTION}

Reefs are endangered worldwide through natural and anthropogenic stressors. In West Sumatra, Indonesia, destructive fishing practices had been going on for decades and destroyed huge areas of the local reefs. Finally, in 2000 a protected area of 20,000 ha was established (MPA Pulau Pieh; [1]) and the partial reef recovery is well documented [2-8]. During monitoring of destructed reefs, a new cryptic mushroom coral species, Podabacia kunzmanni, was detected [9], apparently benefiting from large rubble fields. It was described from shallow reefs only, where fishing with explosives was practiced, attached to dead corals, not common and most specimens were between 5-7 cm in size, with few exceptions. Apart from West Sumatra this species is only reported from the Jakarta Bay and Singapore [9]. Since 2010 regular monitoring in West Sumatra is conducted by a team from the MMAF/KKP (Ministry of Marine Affairs and Fisheries) and yearly field reports are available, where this species is only reported as very occasional - both within and outside the MPA [10].

\section{STUDY LOCATION}

During recent visits in 2018 and 2019, the authors detected numerous specimens, mainly at three locations within the MPA Pulau Pieh (Fig. 1). Particularly at Pulau Pandan $\left(00^{\circ} 65.801 \mathrm{~S} /\right.$ $\left.100^{\circ} 08.326 \mathrm{E}\right)$ more than 50 specimens on a single dive of $45 \mathrm{~min}$ were found. During three dives we found altogether more than 150 specimens. A calculation of the covered distance $(6 \times 50 \mathrm{~m})$ and area $\left(600 \mathrm{~m}^{2}\right)$ yields an estimation of 0.25 specimen $\mathrm{m}^{-2}$. While only few small $P$. kunzmanni $(2-5 \mathrm{~cm})$ were found in the shallow at 4-8 $\mathrm{m}$, most individuals were in greater depth, down to $18 \mathrm{~m}$, reaching diameters of up to $20 \mathrm{~cm}$ (Fig. 2). With regard to size, depth distribution and abundance, these are three new records for this species.

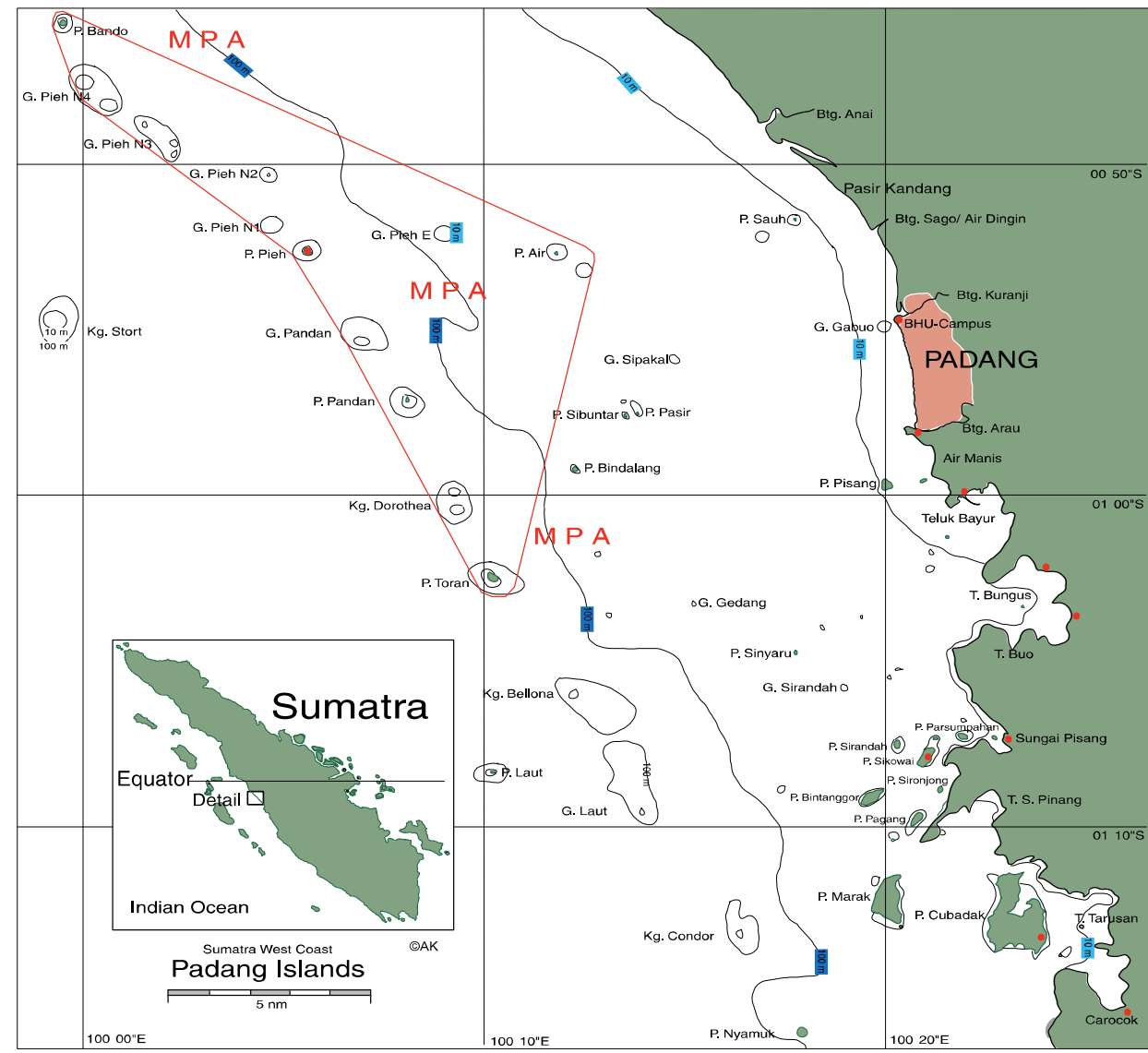

Fig. 1. Map of Padang Islands at the Sumatra West Coast, including the Marine Protected Area (MPA) Pulau Pieh 




Fig. 2. Podabacia kunzmanni at different depths: a) small (in $4 \mathrm{~m}$ ), b) large (in $10 \mathrm{~m}$ ) and c) very large (in $18 \mathrm{~m}$ ), all attached to coral rock 


\section{DISCUSSION AND CONCLUSIONS}

Hoeksema [9] gives two potential explanations for finding them mainly on dead reefs: either they are better survivors or they are better colonizers of dead coral substrata. The fact that regular monitoring in West Sumatra was conducted for the last ten years [10-13] with only very occasional records of this species, suggests that it is not only a better colonizer of dead corals, but also benefitted from recovering reefs, as it was also regularly found in between healthy corals at Pulau Pieh and Pulau Pandan, expanding into greater depth and producing larger specimens. So far there were no additional site records of the species since its original discovery and publication in 2009. Coastal managers of Indonesia and Singapore should therefore apply a precautionary approach and try to get it listed as a CITES species in IUCN's list of endangered species. The team is presently collecting more data on the distribution and the reasons behind the sudden rise in visibility. All stations mentioned in Hoeksema [9] will be investigated.

\section{COMPETING INTERESTS}

Authors have declared that no competing interests exist.

\section{REFERENCES}

1. Kunzmann A. On the way to management of West Sumatra's coastal ecosystems. Naga. 2002;25(1):4-10.

2. Available:http://scorpionfish.zmtbremen.com/startframe.html (access 1.11.20)

3. Available:http://scorpionfish.leibniz-zmt.de (access 1.11.20)

4. Kunzmann A The coral reefs of West Sumatra. In: Tomascik T, Mah AM, Nontji A, Kasim Moosa M (eds). The Ecology of the Indonesian Seas Part two. Periplus Editions (HK) Ltd, Singapore. 1997;12491262.
5. Randall JE, Kunzmann A. Seven new records of fishes from Indonesia, with discussion of western Indian Ocean fishes in southwestern Indonesia. Raffles Bull. Zool. 1998;46(2):477-485.

6. Randall JE, Kunzmann A. Cirrhilabrus adornatus, a new species of labrid fish from Sumatra. Rev. fr. Aquariol. 1998; 25(1-2):41-44.

7. Kunzmann A, Randall JE, Suprihanto I. Checklist of the shore fishes of the Mentawai Islands, Nias Island and the Padang region of West-Sumatra. Naga. 1999;22(1):4-10.

8. Kunzmann A. The marine ecosystems of western Sumatra. In: Sheppard, C (ed.), Seas at the Millennium: An environmental evaluation. Volume 2: Regional chapters, the Indian Ocean to the Pacific. 2000;386387, Pergamon, Amsterdam.

9. Hoeksema, B. Attached mushroom corals (Scleractinia: Fungiidae) in sedimentstressed reef conditions at Singapore, including a new species and a new record. Raffles Bull. Zool., Suppl. 2009;22:81-90.

10. Kunzmann A, Samsuardi A. Century of Change in an Indonesian Coral Reef: Sluiter's Brandewijnsbaai (1890) revisited. Annual Research \& Review in Biology. 2017;13(3):1-7.

11. Kunzmann A. Corals, Fishermen and Tourists. Naga. 2004;27(1-2):15-19.

12. Heery EC, Hoeksema BW, Browne NK, Reimer JD, Angg PO Huang D, Friess DA, Ming Chou L, Loke LHL, Saksena-Taylor $P$, Alsagoff N, Yeemin T, Sutthacheep M, Vo ST, Bos AR, Gumanao GS, Hussein MAS, Waheed Z, Lane DJW, Johan O, Kunzmann A, Jompa J, Suharsono, Taira D, Bauman AG, Todd PA. Urban coral reefs: Degradation and resilience of hard coral assemblages in coastal cities of East and Southeast Asia. Marine Pollution Bulletin. 2018;135: 654-681.

13. Available:https://scorpionfish.leibnizzmt.de/publications (Access 1.11.20)

(c) 2020 Kunzmann et al.; This is an Open Access article distributed under the terms of the Creative Commons Attribution License (http://creativecommons.org/licenses/by/4.0), which permits unrestricted use, distribution, and reproduction in any medium, provided the original work is properly cited.

Peer-review history:

The peer review history for this paper can be accessed here: http://www.sdiarticle4.com/review-history/63060 